\title{
A community needs responsive management training model: Re-envisioning management training for pastors of the International Assemblies of God Church
}

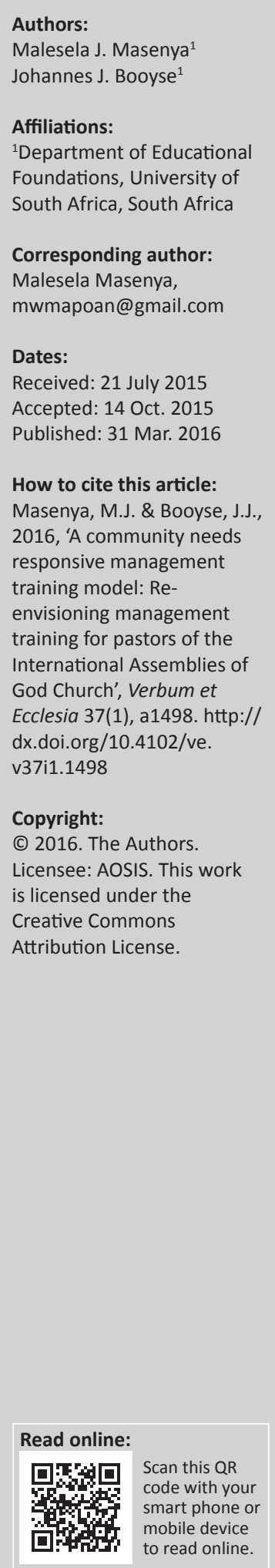

Non-profit organisations (NGO's) play an important role in helping satisfy society's many needs. Churches, for example, are called upon to address critical challenges facing the South African society such as discrepancies in life chances, unemployment and corruption. It largely depends on the management skills of leaders of such organisations to succeed in their endeavour to meet community needs. In order to improve these skills, this study sought to redefine the initial training of student pastors, including their management training, at the colleges of the International Assemblies of God Church (IAG). A qualitative research approach was followed. Two focus group interviews and seven individual interviews were conducted. Interviews included members of the national and provincial executive committees of the IAG, serving pastors, directors of training colleges, pastor trainees in their final year of study, and a newly graduated student. The findings of the study support the importance of formal management training for pastors before being employed in the service of the IAG. This Church has moved away from accepting ministers for service based on their faith and profession of a call to ministry only. The investigation revealed shortcomings in the initial training programmes of pastors; for example, the emphasis on theological courses at the expense of courses that are responsive to community needs and management training issues. Leaders with the competency to respond to community needs are required. The implementation of a transformational management framework, which includes community responsive courses, is recommended as a way to effectively train church leaders.

Intradisciplinary and/or interdisciplinary implications: Although this article is written within the framework of Educational Management, it touches on other fields like Practical Theology and Curriculum Development. It reflects on the perceived need to include management training in the formal preparation of pastors; an aspect which has previously been sorely neglected. A training model is suggested to achieve this objective.

\section{Problem statement and purpose of the article}

Non-profit organisations in South Africa, for example churches, are frequently called upon to help address critical challenges facing society today. These challenges are numerous and, if not addressed adequately, they will eventually cripple communities and lead them to becoming non-functional. Discrepancies in life chances, the HIV and AIDS pandemic, unemployment, corruption, crime, the mushrooming of informal settlements all over urban areas, and service delivery protests are linked to some of these challenges. Nürnberger (2002:76) strongly supports the view that churches should engage in attempts to deal with these challenges and warns that should churches continue to train and produce so-called 'peasant priests' who are unable to serve highly enlightened communities, the new democracy in South Africa can explode into chaos and anarchy. Omulokoli went to great lengths in addressing challenges of poorly trained pastors in the African context (Omulokoli 2002). Smit et al. (2007:4) endorse this pronouncement in showing the huge role that churches play in society by including them among non-profit organisations which help 'satisfy society's many needs'. For these organisations to succeed in addressing these problems, they must be led by effective and efficient leaders who are also seen as convinced and convincing leaders (Masenya 2014:3-4). According to Bolman and Deal (1991:xiii-xiv), 'organisations that are overmanaged but underled eventually lose any sense of spirit and purpose' and 'poorly managed organizations with strong charismatic leaders may soar temporarily only to crash shortly thereafter'. 
In a book on ministerial formation edited by Naidoo, Archbishop Emeritus Desmond Tutu ascribes the inability to effectively address the social ills facing society today to the ineffectiveness of training programmes for pastors, which do not enable students who complete these programmes to:

think theologically, apply what they have learnt to their contexts relevantly, think critically, and act prophetically - that they would exercise their ministerial functions competently and that they would be persons who were growing in their spiritual and prayer life. (Naidoo 2002:x)

Kofi Annan (2013), former secretary-general of the United Nations echoes the same sentiments with regard to addressing social ills like extreme poverty, high levels of inequality, and unemployment. This underlines that the proper training of pastors is crucial. Annan sees religious leaders of our day playing a crucial role in resolving the challenges facing many communities:

There is a crucial role here for Africa's religious leaders in promoting tolerance and understanding of our common humanity. We need them, at every opportunity, to denounce violence, discrimination, including on the grounds of gender and sexuality. Perhaps above all, they must welcome and safeguard the freedoms of all faiths, not just their own. (pp. 1, 3)

There can be little doubt that churches must be managed in an efficient and professional way to accomplish what is expected of them by the communities they serve. It is only logical that the proper management of churches should start with thorough and relevant training of pastors as the future leaders expected to achieve this milestone. As an example to support this stance, scholars in higher education stress the need for accountability in a market-oriented society today (Bessant 1995; Zulu 2007).

However, currently the opposite appears to be true. The stance held by various scholars is that pastors in general, and those of the International Assemblies of God Church (IAG) in particular, are not being trained effectively for their management and administrative roles. Their training in this regard is viewed as below expectation compared to their counterparts in other occupations and institutions (Masenya 2014:1). Researchers such as Bedard (2008) and Rush (1983), for example, have long ago arrived at the conclusion that pastors are trained in theological knowledge at the expense of management and administrative skills. These scholars indicated that the pastors' heads are filled with biblical and theological knowledge to provide spiritual leadership, while trained pastors are found empty-handed in practical areas like handling church finances, strategic planning, staff relations, and church marketing. According to them, pastors were, at that stage, not trained in a competent way so as to feel adequately prepared to manage the organisations they were responsible for. Jackson (1989:10) gives a good summary of this scenario: 'Most seminaries train pastors for leading and caring roles, but few offer courses on how to get along with the governing board, the secretary, or the mimeograph machine'.
It appears as though the apparent lack of managerial and administrative skills of the pastors of the IAG (who constitute the focus of this article), can possibly be traced back to the kind of initial training programmes these pastors have been and are still subjected to in their preparation as future leaders of their congregations. Consequently the point of departure for this article (its central argument) is the following: 'Proper initial management training programmes for trainee pastors in the IAG should satisfy an identified need in their future practices'.

Because it is assumed that proper initial training programmes for trainee pastors should satisfy an identified need in their anticipated daily practices, the question arises whether the initial training programmes at, among others, the colleges of the IAG adequately prepare pastors for service. This question guided the investigation upon which this article is built.

\section{Theoretical framework}

Any research endeavour should be grounded on sound theory. In this regard Merriam (1998:50) points out that any investigator who ignores existing theory, runs the risk of pursuing a trivial problem or duplicating what was already been done. Bush and Bell (2002:5) also explicitly state that 'practice without theory and research neglects previous findings and experience and risks repeating the mistakes of the past'.

In heeding warnings such as these, this article is located in the field of education management and based on curriculum theory, various management models, and a theory of transformational management. A brief discussion of each follows below. In addition, an overview is presented of the nature of pastoral training in other church traditions than that of the IAG.

\section{Literature review}

The training of pastors of four church traditions, namely, the Anglican Church of Southern Africa, the Uniting Dutch Reformed Church in South Africa, the Evangelical Lutheran Church of South Africa, and the Methodist Church of Southern Africa was studied in a bid to provide benchmarking for the training of pastors in the IAG.

Literature revealed that the above church traditions regard the training of pastors as crucial for them to succeed in spreading the gospel and ministering to communities in other aspects of life and to overcome challenges posed by issues like the HIV and AIDS pandemic, poverty, wars, and xenophobic attacks, among others (Masenya 2014:51).

The curriculum of these churches normally stresses a slant towards a strong grounding in theological training and denominational principles.

It is clear that these church traditions take preselection and selection processes which candidates are subjected to 
very seriously. Not only is Grade 12 regarded as the minimum qualification for one to be registered at their training institutions, but discernment and screening processes through the writing of pre-admission examinations, health and psychometric testing, appearance before boards and councils, and a probationary period also plays an important role. These churches follow and advocate vibrant and useful methods of recruitment to make sure that they enrol the very best candidates available.

Generally, these church traditions follow a holistic approach in training, attempting to train the whole person. The development of the person counts more than the content of the curriculum. In that way the churches do take the needs of the communities they serve seriously and thus train transforming leaders for the church and the nation.

These churches, however, do not stress management and leadership as part of their curricula. Management training is only provided by means of a single, elective course. Basic Bookkeeping and Financial Management, as aspects of management training, are mentioned in the curricula of two church traditions and only one church offers Transformational Leadership and Interdisciplinary Knowledge as a leadership module (The College of the Transfiguration 2011; Kumalo \& Richardson unpublished; Nürnberger 2002; The Methodist Church of Southern Africa 2007; URCSA 2011).

In comparison, there is not much written on the training of pastors in the IAG and in this investigation I had to rely on verbal accounts of some of the senior members of this church tradition and its constitution to elicit information on the training of its pastors.

The training of pastors in the IAG dates back to the year 1947 when the Africa Bible Training Institute was founded in Witbank. This training college evolved since then changing names to the African Bible College, the Southern Africa School of Theology, and recently to the Global School of Theology (GST). The latter institution represents an amalgamation of three institutions which operated independently before they were merged, namely the South African School of Theology, the Independent Bible College, and the Cape Theological Seminary. The GST is an affiliate of the Global University (GU) with its headquarters in Springfield, Missouri, USA. The GST has its head office in Roodepoort, Gauteng, and has three regional campuses in Cape Town, North West, and KwaZuluNatal respectively (N.F. Kekana [director of Global School of Theology] pers. comm., 02 April 2009; M.T. Maphori [bishop of the Limpopo District of the International Assemblies of God] pers. comm., 17 April 2011).

The Constitution of the International Assemblies of God (2007:24-26) states the following as prerequisites for candidates to be considered as prospective pastors-intraining and later to be admitted as pastors:

- A definite Scriptural born-again experience.

- The Baptism of the Holy Spirit according to Acts 2:4.
- Acceptance of the International Assemblies of God Constitution and By-Laws.

- Completion of 3 years of Bible training at one of the International Assemblies of God Colleges.

All the three campuses of the GST follow the prescriptions of the GU to the letter and they ensure that candidates write and pass the final examination which is administered by the GU. Pastor trainees must have completed Grade 12 as the minimum requirement for enrolment for a 2-year Diploma in Religious Studies (A decision taken recently in this regard supersedes the prescription of the Constitution) (Undergraduate Programme Information 2013:7, 34).

The content of the Diploma in Religious Studies focuses mainly on theological training based on the Bible, theological practice, and church ministry. The programme followed by pastor trainees of the IAG does not prescribe any course on leadership and management. Some electives like the subject, Church Business, contain elements of management training and students may also opt to register for more general subjects like College Algebra to improve their general knowledge.

\section{Curriculum theory}

A balanced review of the curricula of theological training institutions and making substantiated recommendations for improvements in this regard, are hardly possible without taking into consideration existing theories of curriculum development. The following discussion provides an overview of relevant aspects of curriculum development, including elements of constructivism and postmodernism. The selected points are highlighted by curriculum specialists (Anderson 2009; Brandon \& All 2010; Collins \& Yates 2009; Hull 2009; Liss \& Liazos 2010; Morgan \& Firth 2010; Ornstein, Pajak \& Ornstein 2011; Slattery 2006) and, in this study, served as a rationale for the review of the curricula of IAG training institutions as well as a philosophical grounding for pronouncements made regarding the IAG's training programmes.

A curriculum model should reflect the values of the community for which it is designed and intended. How communities live and perceive the world around them should be mirrored in the curriculum. In that sense a curriculum can never be regarded as neutral. It is designed to uplift the welfare of the community. In the words of Habib (2011:2), the content of the curriculum should advance a progressive social agenda. It is debatable whether a curriculum developed in and by a different community can serve the aspirations of the receiving community and so address its challenges.

The curriculum followed at the colleges of the IAG, at present, was developed elsewhere and as such is susceptible to create problems if it does not address the immediate problems and daily concerns facing the local community. Such a curriculum is likely to affect the work of pastors 
adversely as well. The many social problems discussed and referred to earlier should form part of the curriculum in order to prepare pastoral trainees for what they will be faced with in their work.

A good curriculum should meet the needs of the learners and, in particular, prepare them for life beyond the classroom. The curriculum should therefore be open to new ideas and be geared towards social change and community empowerment.

Though not in practice yet, the IAG is open to learning from other disciplines through borrowing and appropriating relevant knowledge from, for example, the corporate world. The idea of informal training as part of the curriculum augurs well to accommodate this arrangement. Outside institutions and experts can add value to the training of pastors when invited to handle useful content like financial management and conflict resolution which do not fall directly under the scope of formal training.

Curriculum development is not a static occurrence or linear activity, but is ever changing. There is a constant, radical shift towards a new understanding of how different disciplines approach issues. A reconceptualisation of the curriculum emphasises that education should address pertinent issues in society as they evolve (Morgan \& Firth 2010).

Curriculum development should be learner-centred by nature and aim to 'break classroom walls down' in a quest to improve understanding. Learners need to participate in their own learning and have to improve their expression and reporting skills by verbalising their findings. Teamwork is improved when learners work in groups. Leadership skills are developed when group members take turns to lead the discussions. Research is encouraged by instructions to follow up on topics under discussion and to complete additional work in laboratories and libraries, for example looking for meanings of difficult words or enlisting the experience of family members to help resolve problems. Curriculum development also calls for the deconstruction of ideas to move away from stereotypes which used to characterise traditional curriculum development (Slattery 2006).

A curriculum should allow problem solving and avoid traditional methods of learning like the 'teacher-tell' method or the content-driven 'talk and chalk' approach (Houston \& Nakah 2013:390). The intention should be to avoid mechanical learning and to produce life-long learners, creative and critical thinkers, and problem-solvers of the day.

The current underproduction of pastors can be overcome by the production of vibrant thinkers who are enablers, equippers, and teachers in their own right. Such graduates will be better placed to offer training to their church members to provide service in areas of need such as caregiving for HIV and AIDS sufferers, conflict resolution in land and civil disputes, poverty alleviation, and violent protest (Longwe 2013:371).

\section{Insights from three important management models}

Three management models which might have had relevance for the current investigation were considered. After a dedicated search for specific biblical-theological management models, I became convinced that there are no such models available, as yet, to guide the planning and implementation of relevant training programmes for future pastors. The three management models which were developed in other spheres of specialisation and which are briefly discussed here, are the Body-of-Christ Management Model, based on so-called utilisation theory (Heyns 1993), the Irizar Management Model which is built on the 'complexity sciences' (Ugarte, Agirre \& Juaristi 2009), and the PRIME Management Model for medical institutions (Van Zyl \& Nel 2008). These models, in one way or the other, stress, among others, the following aspects which constitute part of the theoretical framework within which this article is located:

- Systems and organisations are in a state of flux and should not be seen as predictable and static. Therefore, the colleges of the IAG, the programmes of the training of pastors, as well as their developmental programmes, should be understood to be complex in nature. In order to improve their practice, colleges should be open to accommodate ideas from outside their own sphere of operation.

- The comanagement of institutions should be encouraged rather than traditional management styles, such as the shepherd-flock and top-down approaches which regard leaders of organisations as the 'know-it-all'. The preferred approach is also referred to as people-oriented or shared leadership where leaders are no longer seen as the sole custodians of authority.

- Delegation of duties to other levels of management promotes effective and efficient management. The expertise of all members in an organisation should be put to good use to benefit the organisation. Thus, there will be room for innovative thinking which releases the creative potential of all members.

- Management processes are more important than the structure of the organisation. The traditional approach of putting hierarchical structures first, instead of taking into account what takes place in practice, does not enhance processes of running organisations. Business organisations are moving away from such a rigid approach in favour of more flexible, democratic management approaches.

- A top-bottom approach in management and being overly committed to structural set-ups rather than to managerial techniques and competencies in an organisation, should be discouraged (Xiaojian \& Tame 2007; Zhu 2008).

The above insights serve as guidelines in determining the content of the curriculum and also for inclusion in the discussions regarding the developmental programmes of pastors.

\section{Transformational management as theoretical framework}

The success of any academic investigation depends on situating it within a relevant theoretical framework. According to 
Sinclair (2007:39), a theoretical framework is 'a relevant theory underpinning the knowledge base of the phenomenon to be researched'. He further shows that this framework can also be referred to as 'theoretical know how' or 'theoretical know what', which is a developmental and experiential journey that ultimately leads to 'sound theory' which has 'demonstrable effects on practice'. Thus, a theoretical framework should be seen as a structure that helps the reader to make sense of the question that the study is founded on (http:/ / www.ask.com; http:/ / smallbusiness.chron.com/definition-transformationalmangement-24540.html).

The research which is being reported in this article was also informed by the theory of transformational management. The idea of transformational change takes into account the nature of an organisation and determines what constitutes an improvement to it (Chapman 2002:16). Transformational change considers appropriate strategies to bring about change, the role of change agents, and ways in which quality can be improved. In this regard, Jones (1993:vi) advocates the total quality improvement or quest for quality theory which he sees as 'a structured, disciplined approach to identifying processes that are not working well; improving the processes; then standardizing and further improving the achievements made'. According to Jones, a system's design leads to the specific results it is getting. If one desires different results, one needs to redesign the system.

Thus, situating this investigation within a transformational management framework suggests that there will be change and transformation regarding the initial management training of pastors as well as the developmental programmes of pastors within the IAG church establishment.

\section{Methodology}

A qualitative research approach was followed to elicit the necessary information to answer the research question. Interviews, participant observation, and document analysis were used to gather information.

Two focus group interviews consisting of five participants each and seven individual interviews were conducted with individuals who were deemed to be information rich and therefore well placed to supply information on the topic under discussion. The participants included members of the national and provincial committees of the IAG (because of their strategic position in the Church as leaders and policy makers) as well as active, practising pastors who have experience of the day to day functioning of congregations and who have undergone standard training themselves. Their involvement in the selection of candidates for future training, made their participation in the interviews even more essential. The participation of past and present students in the interviews was also regarded as critical because of their hands-on experience of current training programmes. Interviews were also conducted with lay members of the church whose views were important to represent the view of the general members of the Church on the training of pastors.
The opinions of participants were sought regarding opportunities and challenges of the training of pastors, selection and preselection requirements, capacity and infrastructure, and curriculum content. All these aspects have got a bearing on the initial training of pastors.

\section{Findings \\ Opportunities and challenges regarding the training of pastors}

It was found that all participants in the study, without exception, supported formal training for the pastors of the IAG. They regarded training as an absolute necessity, unlike in the past when pastors were accepted to serve the Church on the basis of profession of their faith and a calling to ministry. According to the participants the exponential growth of membership of this church also necessitates proper training. There are an estimated 500 million Pentecostals worldwide and one newspaper reported that in South Africa, more than $8 \%$ of the population belong to Pentecostal denominations (City Press 2012:6). The IAG is a member of the family of Pentecostals. This state of affairs affords prospective student pastors an opportunity to still train as pastors. In fact, during one of my visits to the head office of this Church, I observed a manifesto displayed in the reception foyer stating plans to establish 1000 new churches and to train the same number of pastors by the year 2020 .

The interviews also confirmed that receiving training, or 'going to school' (the expression used frequently by participants), is taken for granted provided one has 'received a calling'. One participant expressed the thought as follows: '... in truth before the candidate applies to go to school he or she should have proof of a call from the church' (P3, Male, Pastor, 59 years old). One student participant expressed the idea that the students who are being trained at theological colleges are people of a particularly high calibre. He explained that:

\begin{abstract}
... the majority of the gentlemen who are here, were working and had good jobs before, and they attended other institutions before they responded to the call of God; they are so educated, yet they opted to follow ministry. (P15, Male, Final Year Student, 31 years old)
\end{abstract}

\section{Preselection and selection procedures}

Selection procedures were also carefully scrutinised. Preselection and selection processes are regarded as being below the expected standard. At the time of the research, a letter of recommendation written by the local pastor was the only criterion required for prospective pastors to be accepted as students at the training colleges for pastors. Participants alluded to the disregard by those in authority for important aspects of the selection process like writing a test, appearing before a regional and/or a national selection committee, completing health questionnaires, and psychometric tests. This view can be summarised in the words of one participant who said, '... I do not think it is a rigorous thing...you just fill in the form and they ask a couple of questions about you and 
they find out your background ...' (P17, Female, Student, 21 years old). Another participant mentioned that 'we don't have probably a rigorous selection as other institutions do... we give students one semester to ("prove" themselves and then - MJM) allow their performance to determine their progress'. (P13, Male, Campus Director, 39 years old). Participants felt that there is a need for the introduction of strict, streamlined selection procedures before a candidate is enrolled at the colleges of the IAG.

\section{Capacity and infrastructure}

Lack of proper infrastructure and staff affects the offering of current courses and the possible introduction of new ones negatively. The current meagre staff component leads to staff members engaging in both teaching and administrative work. As one participant mentioned, the already meagre staff component is engaged in what was referred to as 'mixed responsibilities' (P13, Male, Campus Director, 39 years old) which does not allow much flexibility regarding the introduction of new courses.

\section{Curriculum content}

According to the interviews, initial management training programmes at the colleges of the IAG are not adequate to prepare pastors for their future service. The curriculum of the current Diploma in Religious Studies comprises mainly theological courses. It focuses on theological training and disregards other forms of training which would help address the huge demands placed on today's pastor in an ever changing world. One participant decried the fact that the current programmes do not address the needs of society when he mentioned that 'there are programmes that teach how to manage finances, and we are aware that we must improve on those issues' (P6, Male, National Office Bearer, 72 years old). Yet another participant supported the view of the inadequacy of the programmes to address current issues facing the South African society when he remarked that 'even though it is not formal with books, textbooks, and study guides, we have recognised the need to give some informal training, for example, how to deal with conflict' (P13, Male, Campus Director, 39 years old).

Participants felt that current training programmes exclude matters of management and leadership. It is thus seen as inadequate. One participant, for example, expressed the opinion that '... they received little training when it comes to leading and organisation' (P13, Male, campus Director, 39 years old). In general, churches really do not put a high premium on management courses in their curricula.

It appears as though the curriculum content currently utilised for the training of pastors is generally seen as a sign that trainers are not being responsive to challenges facing communities in South Africa and the world over. The scourge of HIV and/or AIDS; a high unemployment rate, especially among the youth; and poor service delivery by local governments are some of the examples cited. It is undoubtedly felt that training institutions should prepare pastors in matters of management and administration in a manner that will enable pastors to face these challenges as part of their day to day practice.

The remarks made by participants during the interviews confirm their awareness of these deficiencies. Their concerns can be summarised by the following view by one of the participants: '... there are programmes that teach how to manage finances, and we are aware that we must improve those issues' (P6, National Office Bearer, 72 years old).

\section{Discussion of findings and recommendations}

The findings above confirm that there are deficiencies in the initial training programmes of pastors of the IAG, particularly regarding the preselection and selection of candidates, capacity of trainers, infrastructure, and the curriculum.

\section{Preselection and selection procedures}

The training of pastors was taken for granted by participants during the interviews. Although participants were not particular about what should be included in the curriculum, the need for prospective pastors to receive training was seen as an absolute necessity.

The participants were, however, not happy with preselection and selection procedures of pastoral candidates. The recommendation made by the local pastor as the only requirement for admission at the colleges of the IAG was perceived as below what the other church traditions, as highlighted under the literature review section, are doing in this regard.

\section{Recommendations}

The following recommendations may help address the shortcomings that were revealed in the findings.

The success of any training model is dependent on the kind of prospective candidates that will be profiled and enlisted for registration. There is a need to have a quality candidate in order to produce a quality graduate. Apart from spiritual requirements of the Church, the following requirements are important for the success of the training programmes:

- There is no stipulation regarding the number of years of membership before one can train as a pastor of this church tradition. It is therefore recommended that the candidate should have an association with the IAG and its traditions of not less than 5 years. Knowing the traditions puts training in its proper perspective as the candidate will be well aware of the vision of this organisation.

- The candidate should formally apply for admission to indicate his or her intention to follow the path of ministry. 
- The candidate should undergo formal psychometric tests and submit a health questionnaire completed by a professional medical practitioner to the district officials entrusted with the selection of prospective candidates.

- The candidate should appear before a selection panel for screening.

The above list of requirements is not exhaustive but serves as a foundation to bring about the necessary awareness regarding the importance of having good selection mechanisms in place, because some of the managerial and other problems experienced by the pastors of the IAG denominations could be traced back to the poor choice of candidates for ministry.

\section{Capacity and infrastructure}

The colleges have experienced a huge decline of student numbers since 1994 mainly because of a lack of sponsorships from external donors and programmes which are not accredited by the Department of Higher Education and Training. The colleges are self-supporting. Consequently waning funds affect the recruitment of qualified staff members and the acquisition of the necessary resources for proper training. The existing staff members are overloaded and at times have to engage in huge amounts of teaching and administrative duties as well.

\section{Recommendations}

- Marketing strategies should be improved by using the social media and visitation to the schools to communicate the need of the community regarding well trained pastors.

- Individual congregations should make financial contributions towards the training of pastors.

- Partnerships with institutions of higher learning would allow lecturers at these institutions to give proper instruction in more theoretical and theological subjects and leave room for the already stretched college staff to handle courses on church traditions and the administrative work.

\section{Curriculum content}

The curriculum currently followed by prospective pastoral students of the IAG was designed in a foreign country and little doubt exists that local stakeholders feel that it does not address the needs of local pastors and the communities they serve. No room is given in the current Diploma in Religious Studies programme to address pertinent issues facing the communities like the HIV and AIDS pandemic, unemployment, corruption, crime, the mushrooming of informal settlements all over urban areas, and service delivery protests coupled with them.

Another serious deficiency is the lack of courses geared towards the development of management and leadership skills. Where they are included, the offerings are of an elective nature, and in other cases the courses are not addressing management and leadership challenges directly.

\section{Recommendations}

Changes should be brought about in the curriculum directed at the initial training of pastors of the IAG. Those in authority, especially the leadership of the colleges, should move from being content with just doing more of what they do know and fronting other programmes, to bringing about improvement in the system (Bolman \& Deal 1991:4).

In this regard a Community Needs Responsive Management Training Model (CNRMTM) is recommended which, as proposed at the beginning of this investigation, is based on transformational management theory. This theory advocates the identification of processes that are not working well in a system, improving them and standardising the improved gains as well as opening it to further improvements. Such a model should also be based on the tenets advocated by curriculum specialists discussed under the theoretical framework above. The proposed model therefore constitutes a curriculum which reflects the values of the community, is learner-centred, produces thinkers and problem-solvers, and prepares the pastors for their task beyond the classroom. The CNRMTM is discussed in a nutshell below.

\section{The Community Needs Responsive Management Training Model}

\section{The acronym, CNRMTM}

The coinage of the acronym, CNRMTM, was motivated by the thinking that a training programme for pastors should include practical aspects of community life. The following explanation of the acronym is therefore context bound. In other words, the concepts adopted for this study, may have different meanings when used by other researchers in different contexts.

C - 'Community' refers to citizens of South Africa in all the nine provinces. Members of the IAG are found dispersed among people who constitute this community. Pastors should be aware that their main priority should be the improvement of the lot of local people and their first responsibility should be towards their own people.

$\mathrm{N}$ - 'Needs' encompasses the essentials or useful means that any group of people require to survive physiologically or psychologically. The IAG community has both spiritual and practical needs. Today's pastors are encouraged to move away from the overemphasis on meeting spiritual needs and thereby neglecting other, more practical needs which leave the members leading an unbalanced and incomplete life.

$\mathrm{R}$ - 'Responsive' implies answering the challenges facing communities such as poverty, disease, lack of resources, unemployment and societal conflicts, responsibly and sympathetically. The list of such challenges is long and not uncommon to the South African society. Being responsive implies a reaction to and doing something about the plight of others. 
M - 'Management' relates to the course(s) or subject(s) that gives student pastors an opportunity to qualify in matters of leadership and management of their churches. A pastor who is schooled in management will undoubtedly be better placed to handle church matters with more ease than the one who lacks such training.

T - 'Training' refers to teaching vocational and/or practical skills to pastors and thus equipping them through their initial training activities to improve their performance, capabilities, capacity, and productivity.

M - 'Model', refers to the best possible exemplification of a programme that can be considered for implementation at the colleges of the IAG in total or some of its aspects which are perceived to possibly help improve the quality of training.

\section{Proposed course structure}

The 3-year curriculum structure should include core subjects (theological education), basic subjects (foundational education), compulsory subjects (vocational education), and elective or informal subjects (community responsive education). It is left to the IAG to decide on what courses to include as core subjects (theological grounding subjects). The following are examples of subject fields which any curriculum committee may consider at any level of study:

- Basic subjects: Church Traditions and Polity, Church History in South Africa, Communicative English and Academic Report Writing, and Computer Literacy.

- Compulsory or Specialisation: Health Track, Youth Track, Children Ministry, Developmental Track, HIV and AIDS Studies, Counselling, and Leadership and Management.

- Electives or Informal Training: Gender Studies, Urban and Rural Development Studies, Poverty Eradication, Conflict Resolution, Additional African Language, Basic Bookkeeping, and HIV and AIDS Studies.

\section{Conclusion}

Challenges facing South African communities today are numerous and huge in a fast-changing world which is forever in a state of flux. For churches to make a contribution towards the solution of these problems, they should be led by convinced and convincing pastors who answer to the many societal ills. If an organisation like the IAG intends to answer this call, it should review its initial training programmes for pastors from time to time. The proposed CNRMTM is an open vehicle which will hopefully allow training institutions to adapt their programmes around it. It might be useful to open dialogue in matters of the initial and further training of pastors. It is grounded in a sound theoretical basis and opens a way for the inclusion of programmes which are an absolute necessity in the training of pastors, including management training. It is therefore recommended that curriculum specialists, lawmakers and the Department of Education as the accreditation body of training in South Africa, consider this model in curriculation matters.

\section{Acknowledgements Competing interests}

The authors declare that they have no financial or personal relationships which may have inappropriately influenced them in writing this article.

\section{Authors' contributions}

M.J.M. compiled the article based on his DEd thesis which deals with the same topic. J.J.B. was M.J.M.'s supervisor and made conceptual and editorial contributions to the article.

\section{References}

Anderson, J., 2009, 'National curriculum development and initial reflections on the mathematics framing paper', Australian Mathematics Teacher 65(1), 14-16.

Annan, K., 2013, 'The way forward for our continent', Unpublished paper read at the Annual Desmond Tutu International Peace Lecture, University of the Western Cape, Cape Town.

Bedard, R.L., 2008, 'Emerging models of ministerial training for Pentecostal Assemblies of Canada', Unpublished doctoral thesis, University of South Africa, Pretoria.

Bessant, B., 1995, 'Corporate management and its penetration of university administration and government', Australian Universities Review 33(1), 11-15.

Bolman, L.G. \& Deal, T.E., 1991, Reframing organizations: Artistry, choice, and leadership, Jossey-Bass, San Francisco, CA.

Brandon, A.F. \& All, A.C., 2010, 'Constructivism theory analysis and application to curricula', Nursing Education Perspectives 31(2), 89-92.

Bush, T. \& Bell, L. (eds.), 2002, The principles and practice of educational management, Paul Chapman, London.

Chapman, J.A., 2002, 'A framework for transformational change in organisations', Leadership \& Organization Development Journal 23(1), 16-25.

City Press, 2012, 'Formal churches lose their flocks', Johannesburg: City Press, 08 April, p. 6

Collins, C. \& Yates, L., 2009, 'Curriculum policy in South Australia since the 1970s: The quest for commonality', Australian Journal of Education 53(2), 125-140.

Global School of Theology, 2013, Global School of Theology, Undergraduate Programme Information 2013, Unpublished document.

Habib, A., 2011, 'Managing higher education institutions in contemporary South Africa: Advancing progressive agendas in neo-liberal and technicist world', Paper presented at a colloquium, University of South Africa, Pretoria.

Heyns, L., 1993, 'Bestuur van die gemeente as organisasie van vrywilligers', Praktiese Teologie in SA 8(2), 126-136.

Houston, B. \& Nakah V., 2013, 'Theological education in evangelical churches', in I.A. Phiri \& D. Werner (eds.), Handbook of theological education in Africa, pp. 386-392, Cluster, Dorpspruit.

Hull, J.E., 2009, 'Education for discipleship: A curriculum orientation for Christian educators', Journal of Education \& Christian Belief 13(2), 155-168.

International Assemblies of God, 2007, International Assemblies of God, Constitution and By-Laws, Unpublished document.

International Assemblies of God Sa, n.d., International Assemblies of God Manifesto, Unpublished document.

Jackson, J., 1989, 'How to be a pastor and manager', Christian Ministry 20S 0, 8-10.

Jones, E.E., 1993, Quest for quality in the church: A new paradigm, Discipleship Resources, Nashville.

Kumalo, S. \& Richardson, N., Unpublished, Seth Mokitimi and education for ministry: What's in a name?

Liss, J.R. \& Liazos, A., 2010, 'Incorporating education for civic and social responsibility into the undergraduate curriculum', Change, January/February, pp. 45-50.

Longwe, H., 2013, 'Major concepts and understandings of theological education in Baptist churches in Eastern and Southern Africa', in I.A. Phiri \& D. Werner (eds.) Handbook of theological education in Africa, pp. 363-379, Cluster Publications: Dorpspruit.

Masenya, M.J., 2014, 'Re-envisioning management training of pastors in the colleges of the International Assemblies of God (IAG) of South Africa', Unpublished doctoral thesis, University of South Africa.

Merriam, S.B., 1998, Qualitative research and case study applications in education (revised and expanded from case study research in education), Jossey-Bass, San Francisco, CA.

Morgan, J. \& Firth, R., 2010, 'By our theories shall you know us', the role of theory in geographical education', International Research in Geographical and Environmental Education 19(2), 87-90.

Naidoo, M. (ed.), 2012, Between the real and the ideal: Ministerial formation in South African churches, University of South Africa, Pretoria. 
Nürnberger, K., 2002, 'Ministerial training for the 21st century: A South African case study', Ministerial Formation 98-99 JI-0, 76-83.

Omulokoli, W.A.O., 2002, 'The challenge of leadership training for churches in post independence Africa', AICMAR Bulletin 1, 46-60.

Ornstein, A.C., Pajak, E.F. \& Ornstein, S.B. (eds.), 2011, Contemporary issues in curriculum, 5th edn., Pearson, Boston, MA.

Rush, M., 1983, Management: A biblical approach, SP Publications, Wheaton.

Sinclair, M., 2007, 'A guide to understanding theoretical and conceptual frameworks', Evidence Based Midwifery 5(2), 39.

Slattery, P., 2006, Curriculum development in the postmodern era, 2nd edn., Routledge, New York.

Smit, P.J., De J Cronjé, T., Brevis, T. \& Vrba, M.J. (eds.), 2007, Management principles: A contemporary edition for Africa, Juta \& Co, Cape Town.

The College of the Transfiguration, 2011, The College of the Transfiguration (COTT) Prospectus 2011, Unpublished document.

The Methodist Church of Southern Africa (Education for Ministry and Mission Unit), 2007, Candidating for the Ordained Ministry, Procedures and Application Forms for 2007, Silverton, Unpublished document.

Theoretical framework, viewed 23 September 2013, from http://www.ask.com/ question/what-is-the-meaning-of-theoretical-framework
Transformational management, viewed 20 September 2013, from http://small business.chron.com/definition-transformational-mangement-24540.html and http://www.ask.com

Ugarte, L., Agirre, A. \& Juaristi, E., 2009, 'The cohesive power of new management alternatives: Principal components of the Irizar model', International Journal of Technology Management and Sustainable Development 8(1), 13-26.

Uniting Reformed Church in Southern Africa, 2011, Uniting Reformed Church in Southern Africa (URCSA). Manual for Ministerial Formation, Unpublished document.

Van Zyl, G.J. \& Nel, M.M., 2008, 'The PRIME model: A management solution in academic medicine', South African Family Practice 50(1), 71, 71a-71c.

Xiaojian, W. \& Tame, G., 2007, 'How Chinese management development practices differ from Western models', People Management 13(19), 62.

Zhu, Z., 2008, 'Trade-offs between the top-down and bottom-up school education management models (the implementation of school development planning in Western China)', Chinese Education and Society 41(5), 36-57.

Zulu, C.B., 2007, A comparative study of women in management in higher education in South Africa and the United Kingdom, Unpublished doctoral thesis, University of South Africa, Pretoria. 